\section{OP2-025 前立腺生検所見と病期の関連性}

済生会下関総合病院泌尿器科 ${ }^{1)}$, 町立大和総合病院泌尿 器科2), 北九州総合病院病理 ${ }^{3)}$

江口 賢", 白石 晃司", 毛利 淳", 上領 頼啓",

井本 勝彦穾, 藤 隼人 $^{3)}$

【目的】当院に扔いて前立腺生検を行い限局性前立腺癌の 診断の下、根治的前立腺全摘術を行った症例で手術前の 各種パラメーターと前立腺摘出標本の関連性について検 討した。

【対象と方法】対象は 1997 年 7 月から 2002 年 6 月にかけ PSA 高值にて系統的前立腺生検を施行し前立腺癌と診 断され neoadjuvant therapy を行わず根治的前立腺全摘 術を施行した症例である。術前の PSA 值、F/T PSA 比、 術前の生検組織の病理学的所見と前立腺摘出標本の組織 型、Gleason score、浸潤進展度、腫瘍体積との関連性に ついて分析し検討した。

【結果】52 症例で平均年齢 66.2 歳、平均術前 PSA13.3ng/ $\mathrm{ml}$ 、平均前立腺容積 $28.4 \mathrm{ml}$ であった。

\section{OP2-026 前立腺癌被膜外進展の術前予測因子と しての針生検陽性率の有用性}

\section{兵庫県立成人病センター泌尿器科}

酒井 伊織, 原田 健一, 三宅 秀明, 江藤 弘

【目的】前立腺癌被膜外進展の術前予測因子としての針生検 陽性率の有用性を検討し, 6 力所あるいは 8 力所生検のい ずれを基に針生検陽性率を算出するのがより有用であるか を併せて比較した。 [対象と方法] 1999 年 1 月より 2003 年 8 月までに, 当科で 8 力所生検を施行し前立腺癌と診断され た症例の内, 術前内分泌療法を併用せず根治的前立腺全摘 除術を施行した前立腺癌 88 症例を対象とし, 術前PSA 值, 生検 Gleason score, 腫瘍の偏側性, 全生検標本中の腫瘍占 拠率㧍よび針生検陽性率が, 前立腺癌被膜外進展の術前予 測因子となりうるかを検討した.【結果】手術時の年齢およ び PSA の中央值は, それぞれ 70 歳扩よび $9.1 \mathrm{ng} / \mathrm{ml}$, 病理 学的病期は $\mathrm{pT} 2$ および $\mathrm{pT} 3$ 以上が，それぞれ 48 および 40 症例であった. 術前 PSA 值, 腫崵占拠率および針生検陽性 率が被膜外進展の有意な術前子測因子であり,この 3 因子 の中で針生梌陽性率が最も有用な予測因子であった。 また, 標準的 6 力所生娭を施行したと仮定し算出した針生検陽性 率の方が，8方所生検に㧍ける陽性率より優れた予測因子 であった。[結論]針生検陽性率は, 前立腺癌被膜外進展の術 前子測因子として有用であり, 被膜外進展の予測を行う際 には 6 ケ所を超える標本を採取していても，標準的な 6 ケ 所で針生検陽性率を算出するべきと考えられた。
OP2-027 針生桱、直腸診、PSA 值による神経筋 束浸潤の有無の予測

名古屋第二赤十字病院、病理部", ジョーンズホプキン ス病院2), ジョーンズホプキンス病院 ${ }^{3)}$, ジョーンズホ プキンス病院

都築 豊徳", エーディーン ハッカン2), ヘルナンデス デビッド3),トロック ブルース ${ }^{4)}$, ウオルッシュ パトッリクア゙,エプスタイン ジョナサン2 [目的]前立腺癌に拉计万前立腺全摘術において、神経温存術の道否は重 要な問題である。針生㛟特の Gleason score、直腸診、PSA 值による被膜 浸潤の予貺は試みられているが、神経筋束周团の浸潤に焦点を当てた検 討は少ない。[方法]The Johns Hopkins Hospital にて前立腺全摘術を行わ れた臨床病期 $\mathrm{T} 1$ 及び $\mathrm{T} 2$ の症例 2660 例の針生検及び手術標本を梌討対 象とした。腫場が前立腺内に限局したもの、神経筋束に浸潤したもの、神 経筋束以外に浸潤したものの 3 群に分類した。検討対象は針生検力陽性 であった葉のみとした。それそれれの群に対し、年龄、PSA 值、直腸診、 針生検での Gleason score、針生検の陽性率、針生検一本当たりの平均腫

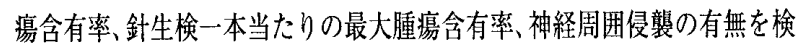
討し、多変量解析を行った。成績及び結論]検討対象葉数は前立腺限局病 変 2070 葉、神経筋束浸潤 620 葉、神経筋束以外の浸润 316 葉であった。 神経筋束浸潤の予測には年齢、針生検の Gleason score、陽性率、平均腫 瘍含有率、直腸診、PSA 值が有用であった。年齢70歳以上、PSA10 以上、 Gleason score 7 以上、陽性率 $20 \%$ 以上、平均埂凚含有率 $33.3 \%$ 以上、直 晹診異常の 6 項目中、2 項目以上の該当所見を認める場合には、10\%の亲 却率で、神経筋束浸潤が存在することが示された。

\section{OP2-028 Template を利用した前立腺多数笛所 生検（Shotgun Bx）で得られた病理所 見と前立腺全摘標本との比較：正確な 癌病巣の診断は可能か?}

\section{札幌厚生病院泌尿器科", 札幌厚生病院臨床工学科 ${ }^{2}$, 札幌厚生病院病理科 ${ }^{3}$, 自衛隊札幌病院泌尿器科 4 , 北 海道大学大学院医学研究科腎泌尿器外科学 5 )}

出村 孝義" 森久保 忍 ${ }^{2)}$, 石川 俊行 ${ }^{2)}$, 橋本 佳苗 ${ }^{2)}$, 室橋 高男 ${ }^{22}$,

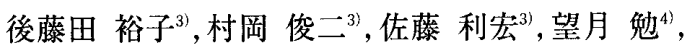
古野 剛史 ${ }^{5)}$

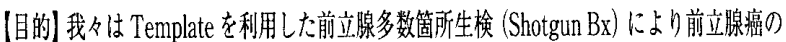

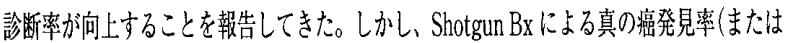

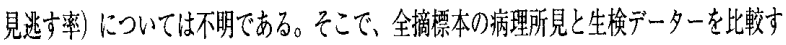

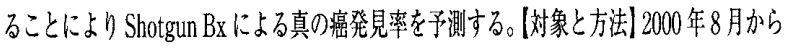

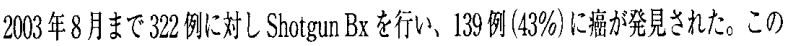

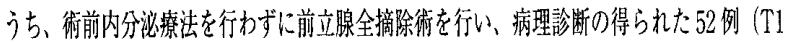

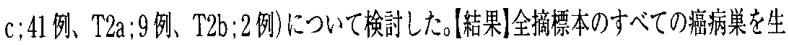

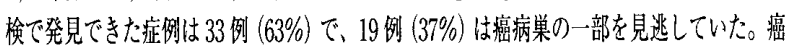

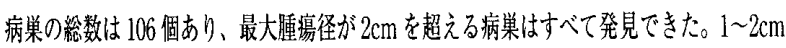

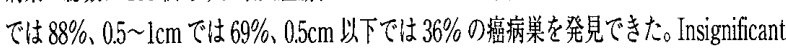

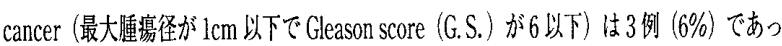

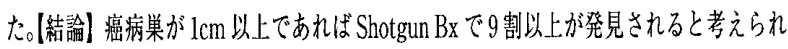

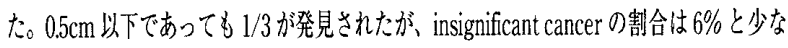

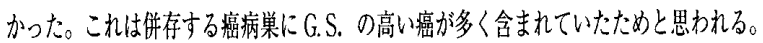

